Vet. Res. (2008) 39:45

www.vetres.org

DOI: $10.1051 /$ vetres:2008022

C) INRA, EDP Sciences, 2008

Review article

\title{
Bovine papillomaviruses, papillomas and cancer in cattle
}

\author{
Giuseppe BorZacchiello*, Franco Roperto
}

Department of Pathology and Animal health, Faculty of Veterinary Medicine, Naples University "Federico II", Via F. Delpino, 1 - 80137, Naples, Italy

(Received 27 November 2007; accepted 7 May 2008)

\begin{abstract}
Bovine papillomaviruses (BPV) are DNA oncogenic viruses inducing hyperplastic benign lesions of both cutaneous and mucosal epithelia in cattle. Ten (BPV 1-10) different viral genotypes have been characterised so far. BPV 1-10 are all strictly species-specific but BPV 1/2 may also infect equids inducing fibroblastic tumours. These benign lesions generally regress but may also occasionally persist, leading to a high risk of evolving into cancer, particularly in the presence of environmental carcinogenic co-factors. Among these, bracken fern is the most extensively studied. The synergism between immunosuppressants and carcinogenic principles from bracken fern and the virus has been experimentally demonstrated for both urinary bladder and alimentary canal cancer in cows whose diets were based on this plant. BPV associated tumours have veterinary and agricultural relevance in their own right, although they have also been studied as a relevant model of Human papillomavirus (HPV). Recent insights into BPV biology have paved the way to new fields of speculation on the role of these viruses in neoplastic transformation of cells other than epithelial ones. This review will briefly summarise BPV genome organization, will describe in greater detail the functions of viral oncoproteins, the interaction between the virus and co-carcinogens in tumour development; relevant aspects of immunity and vaccines will also be discussed.
\end{abstract}

cancer / cattle / co-factor / Papillomavirus / viruses

\section{Table of contents}

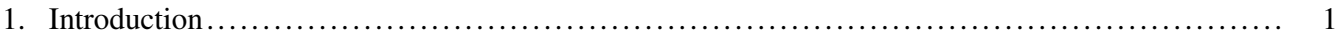

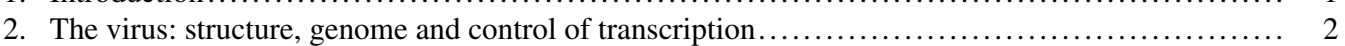

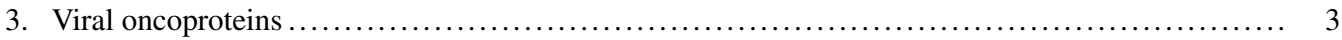

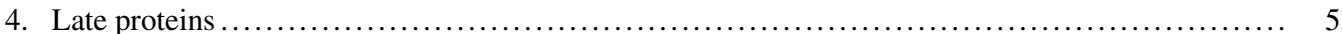

5. Natural history of BPV infection: papillomas and fibropapillomas ............................ 5

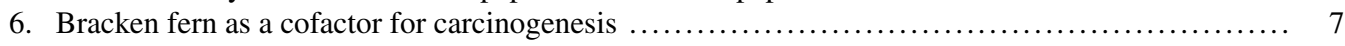

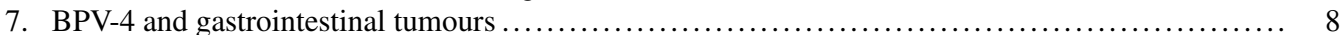

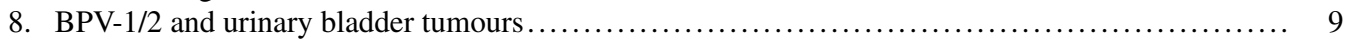

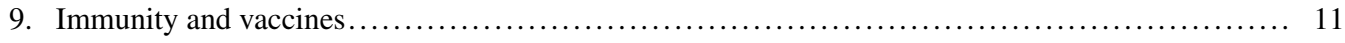

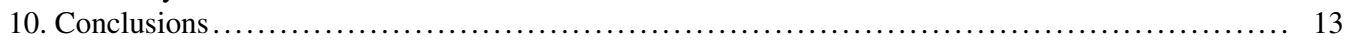

\section{INTRODUCTION}

Bovine papillomaviruses (BPV) belong to the Papillomavirus (PV) genus. These are small DNA viruses infecting humans as well as many domestic and wild animal species, including birds, causing benign

* Corresponding author: borzacch@unina.it hyperproliferative lesions of both mucosal and cutaneous epithelia [62, 130,131].

BPV are strictly species-specific, and, even in experimental conditions, do not infect any host other than the natural one. The only known case of cross-species infection is for horses and other equids by BPV type 1 (BPV-1) or BPV type 2 (BPV-2) [36]. 
BPV infections usually regress, but may occasionally evolve into cancer of both epithelial and mesenchymal origin. Healthy cattle normally recover from papillomas, but in animals grazing on bracken fern (Pteridium aquilinum), there is a good correlation between persistent papillomatosis and cancer [23, 66]. Cattle feeding on bracken fern develop upper alimentary canal and urinary bladder cancers, the former being associated with the presence of the BPV-4 and the latter with BPV-2.

BPV induces diseases of considerable veterinary importance in farm animals, but has also an enormous value as an in vivo model for HPV. In fact, due to the high speciesspecificity of Papillomaviruses, virologists have used BPV as a model for the study of HPV infection, its interaction with the host and with environmental co-factors.

\section{THE VIRUS: STRUCTURE, GENOME AND CONTROL OF TRANSCRIPTION}

Ten BPV types (BPV 1-10) have been characterised and associated with different histopathological lesions. The different genotypes have been classified into three genera [47]:

Xipapillomaviruses encompassing the pure epitheliotropic BPV-3; BPV-4 and BPV-6; Deltapapillomaviruses encompassing BPV-1 and BPV-2, associated with fibropapillomas (i.e. benign tumours of both the epithelium and underlying derma) and Epsilonpapillomavirus comprising BPV-5 whose genome seems to share similarities with the former two BPV groups. In addition, sixteen novel putative BPV have been characterised by sequence determination of the highly conserved L1 region and by phylogenetic analysis [6]. Two novel BPV were characterised further and the phylogenetic analysis showed that both viruses were new BPV types: one was designated as BPV-7 and classified as a member of a new PV genus, and the other was designated as BPV-8 and classified as a member of the Epsilonpapillomavirus genus [95, 134].

Recently, Hamata et al. [59] identified two new BPV types belonging to the genus Xipapillomavirus designed as BPV-9 and BPV-10.
The BPV virion is a non-enveloped icosahedral structure of $55-60 \mathrm{~nm}$ diameter which forms paracrystalline particles in the nuclei of infected cells; it contains a double-stranded covalentely closed circular DNA of approximately 8000 nucleotides complexed with cellular histones.

The structure of the virion has been recently described with an atomic model showing the L1 protein to be exposed on the viral surface, thus suggesting to have a role in infection and in immunogenicity [87]. Three different regions compose the genome: the long control region (LCR) containing the elements necessary for replication and transcription of the viral DNA, and two regions containing open reading frames (ORF) corresponding to early and late genes. The early genes encode for proteins involved in both viral DNA replication and transcription and cell transformation; the late genes encode for capsid proteins. The genomes of BPV-3, BPV-4 and BPV-6 lack the E6 ORF-which has been replaced by the E5 (originally defined as E8), whereas, similarly to most PV types, BPV-1, BPV-2 and BPV-5 still retain this gene. $\mathrm{LCR}$ is a non-coding genome region of approximatively 500-1000 nucleotides (nt) between the 3'-end of the late ORF and the 5'-end of the early ORF. LCR contains all the regulatory signals for both viral DNA replication and transcription. The LCR of BPV-1, BPV-2 and BPV-5 has twelve E2 binding sites, whereas four E2 binding sites are recognised in BPV-3, BPV-4 and BPV-6 LCR. The binding of the E2(2) and E2(3) sites with E2 proteins induces transcriptional repression, whereas the binding of the E2(1) and dE2 sites results in transcriptional activation. In addition, the binding of E2(1) with E2(2) is more stable than complexes formed by the E2(3) and E2(4) sites [64]. However, the BPV-4 LCR has multiple positive and negative regulatory elements able to act independently of E2. Among these, the best characterised cellular transcription factor is PEBP2, which binds to the E2(2) site [64].

While the E1 protein functions in viral DNA replication [76], E2 binding to LCR activates or represses transcription of the viral genes. Another relevant function of 
E2 is its ability to segregate episomal BPV genomes to daughter cells, following cell division, by tethering them to mitotic chromosomes, thus ensuring equal distribution and retention of viral DNA [12]. The BPV-1 E2 protein associates with mitotic chromatin via the aminoterminal domain of the protein and once bound is able to interact with the viral genomes via the carboxyl terminus dimerisation and DNA binding domain $[1,63,78,125]$. For the association of the E2 with mitotic chromatin, the phosphorylation status of the E2 protein is not required [11], and it is likely that the cellular protein Brd4, is responsible for the interaction of E2 with the mitotic chromosomes [141]. It contains different domains and the one responsible for interaction with E2 has been identified [143].

The E4 ORF encodes for small proteins which are very abundant only in the cytoplasm of keratinocytes supporting the productive phase of viral DNA replication [5]. Many groups have found that E4 is associated with the cytokeratins both in cell lines and in natural infections. In some cases, the association results in reorganisation of the cytoskeleton. Whether this interaction may help the replication of the virus in vivo is still to be clarified $[49,108]$.

\section{VIRAL ONCOPROTEINS}

\subsection{E5}

Papillomavirus E5 proteins are short hydrophobic polypeptides (from 42 aminoacid residues in BPV-4 to 83 residues in Human papillomavirus type 16 (HPV-16)), many of which have transforming activity. E5 from different PV have a common structure with an $\alpha$-helical configuration with one trans-membrane span for BPV E5 [133].

The BPV-1 E5 oncogene encodes for a 44-amino acid protein, i.e., the major BPV transforming oncoprotein. It is a type II transmembrane protein expressed in the deep layers of the infected epithelia [5, 25, 139] and is largely localised in the membranes of the endoplasmic reticulum (ER) and the Golgi apparatus (GA) of the host cells; occasionally,

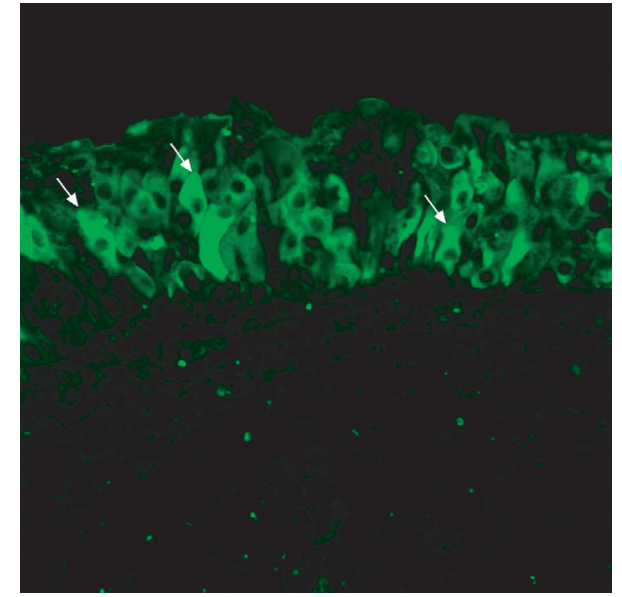

Figure 1. BPV-2 positive bovine urinary bladder cancer. Some neoplastic cells showing a juxtanuclear E5 staining are shown (white arrows). Reproduced with permission from the Society of General Microbiology. Magnification $\times 120$.

when overexpressed in cell cultures, it is also found in plasma membranes [24, 100]. In naturally infected tissues, BPV E5 is expressed in the cytoplasm of both basal and suprabasal transformed epithelial cells with a typical juxtanuclear pattern due to its localisation in the GA (Fig. 1). High amounts of the protein may be observed in the differentiated keratinocytes of skin warts, where it shows a granular staining pattern associated with the sites of viral capsid synthesis [25]. It may also be expressed in neoplastic cells of mesenchymal origin such as those of endothelial origin [22].

BPV E5 has no intrinsic enzymatic activity and its transformation is related to the activation of several kinases, from growth factor receptors to cdk cyclins. It induces morphologic and tumourigenic transformation in rodent and human fibroblasts [116, 117], increases focus formation in NIH3T3 cells when co-expressed with receptor protein tyrosine kinases (PTK receptors) [83], and promotes DNA synthesis in quiescent fibroblasts [119]. The E5 proteins of both BPV and HPV bind a $16 \mathrm{kDa}$ cellular protein. The $16 \mathrm{kDa}$ protein is a multifunctional protein 
with four transmembrane domains: as 'ductin', it is a component of the connexon, the channel that allows intercellular communication through gap junctions responsible for homeostasis; as 'subunit c', it is a component of the V0 sector of the vacuolar $\mathrm{H}^{+}$-ATPase (V-ATPase) which in mammalian cells and in yeast is responsible for the acidification of the endomembrane compartments $[43,56]$. In cells expressing HPV E5, gap junction intercellular communication is inhibited [51,94] possibly due to the interaction between E5 and $16 \mathrm{kDa}$. It is likely that the down-regulation of the gap junction by E5 makes the transformed cells refractory to growth inhibitory signals from neighbouring cells. In support of this hypothesis is the closure of cell-cell communication that takes place during tumour progression [61]. As a result of the interaction between BPV E5 and V-ATPase, the acidification of the lumen of the intracellular compartments (endosomes, lysosomes, and GA) is impaired [115]. BPV-4 E5 transformed cells exhibit a swollen and fragmented GA [8]. Moreover, the alkalinisation of GA affects the trafficking of many important growth regulatory proteins on their way to their final destination in the cell. Thus, the ability of E5 to perturb the $\mathrm{pH}$ of intracellular organelles may influence the activity of many proteins and contribute to cell transformation. An important consequence of E5 mediated impaired acidification is the down-regulation (both in vivo and in vitro) of Major Histocompatibility Complex class I (MHC-I) expression, representing one of the mechanisms by which BPV evades the host's immunoresponse [9]. Down-regulation of MHC-I takes place at multiple levels: the transcription of the gene is reduced, the MHC-I heavy chain peptide is degraded [9] and the MHC-I complex is sequestered in the GA cisternae and prevented from reaching the cell surface [81]. The molecular mechanism by which BPV-1 E5 induces cell transformation lies in its binding to, and activation of, the cellular $\beta$ receptor for the platelet-derived growth factor (PDGF $\beta$ ) [48]. The viral oncoprotein and the receptor form stable complexes, in which the two proteins are in opposite orientation and E5 interacts with the transmembrane and juxtamembrane domains of the PDGF-R $[41,50,103,128]$. The activation of endogenous PDGF $\beta$ receptors is characterised by the formation of stable complexes, persistent tyrosine phosphorylation of the receptor, its dimerisation and cellular transformation. Interestingly, this interaction also takes place in naturally occurring tumours, confirming the role of the protein complex in cancer development [21].

In E5 transformed cells there is a constitutive association between the receptor and phospholipase $\mathrm{C} \gamma$, phospho-inositol 3-kinase (PI3-K) and ras GTPase activating protein, and $\mathrm{SH} 2$ domain-containing cellular proteins, which play essential roles in the response to PDGF [40, 50, 57, 75, 102]. Cell lines lacking endogenous PTK receptors demonstrate that only the PDGF $\beta$ receptor cooperates with E5, and that its activation is required for cell transformation by E5 [50,90].

However, certain E5 mutants transform cells without binding to, or activating, PDGF-R. Cells transfected with E5 mutants show elevated PI3-K levels, indicating that E5 can utilise different signalling pathways to activate PI3-K and mediate cell transformation $[127,132]$. Conversely there are mutant E5 proteins that complex with the PDGF-R and cause receptor tyrosine phosphorylation, but are incapable of cell transformation [85,89].

E5 can also regulate functions related to cyclins and the associated kinases (cdk) affecting the cell cycle. BPV-4 E5 induces increased transcription of the cyclin $A$ gene and elevated expression of cyclin A, accompanied by higher cyclin A-cdk kinase activity. Sustained activation of cyclin A-cdk complex is likely to be responsible for the continued growth of BPV-4 E5 transformed cells in low serum and in suspension $[92,93]$.

An effect of BPV-4 E5 transformation is the increase in $\mathrm{p} 27^{\mathrm{Kip} 1}$ levels, which is a negative regulator of cyclin activity [91]. It has been proposed that BPV-4 E5 induces a coordinated increase in $\mathrm{p} 27^{\mathrm{Kip} 1}$ and cyclin D1-cdk4, which, together with increased cyclin A-cdk activity, allow continued cell proliferation as well as anchorage independent growth of cultured cells [93,142]. 


\subsection{E6}

The BPV-1 E6 gene of Xi BPV encodes an oncoprotein of 137 amino acids able to transform cells. It interacts with CBP/p300 in the same way as described for the E6 proteins of oncogenic Human papillomaviruses. This interaction inhibits the transcriptional coactivator function of $\mathrm{CBP} / \mathrm{p} 300$ required by $\mathrm{p} 53$ and probably by other transcription factors. The E6-CBP/p300 interaction may be necessary, albeit insufficient, for cell transformation, and the transcriptional activator function inherent to the E6 protein is not derived from forming a complex with CBP/p300 [144]. E6 can transform fibroblasts and induce anchorage-independent growth and disassembly of the actin stress fibers by interacting with the focal adhesion protein, paxillin. E6 disruption of the actin stress fibers occurs by blocking the interaction of paxillin with its cellular effectors, such as vinculin and the focal adhesion kinase [135]. Finally, E6 interacts with AP-1, the TGN (trans-Golgi network)-specific clathrin adaptor complex. Cytosolic BPV-1 E6 is first recruited into the TGN, where it is then recognised by membrane-bound AP-1 and subsequently recruited by TGN-derived clathrin-coated vesicles. This interaction can affect cellular processes involving the clathrinmediated trafficking pathway [136].

\subsection{E7}

The BPV-1 E7gene encodes a 127 aminoacid zinc binding protein which cooperates with E5 and E6 in inducing cell transformation. In naturally infected cells, BPV-1 E7 expression is observed in both the cytoplasm and nucleoli of cells belonging to the basal and lower spinous layers, whereas BPV-4 E7 expression is observed in all layers of papillomas, at all stages. Once E7 is coexpressed with E5 and E6, its transformation capacity increases many fold [14]; such co-expression may also occur in tumours of mesenchymal origin [22]. Mutants lacking the E7 open reading frame are still able to induce transformation but at a lower efficiency, and produce transformants with altered characteristics [114].
BPV-1 E7 transformation function has recently been shown to correlate with its binding to a cellular target p600. E7 mutant proteins impair their ability to bind p600 and are transformation defective. Additionally, knockdown of p600 reduces the transformation of cells expressing BPV-1 E7 [45]. Thus, the transformation activity of E7 is mediated, at least in part, by its ability to bind p600. It has recently been shown that BPV-1 E7 can inhibit anoikis, a type of apoptosis induced upon cell detachment. The inhibition of anoikis partially correlates with the ability to enhance anchorage independence of BPV-1 E6-transformed cells [46].

\section{LATE PROTEINS}

The viral genome also contains the late genes encoding for the major L1 and the minor L2 capsid proteins. The L1 mediates virus binding to the cell surface although it seems that L2 may also play a role in infection. L1 interacts with cell surface heparin sulphate proteoglycans and it is still unclear whether a secondary receptor is also involved [44].

L2 induces virion assembly by binding to viral DNA. It is detected solely as a nuclear antigen in the differentiated layers, being most abundant in mature papillomas [5].

\section{NATURAL HISTORY OF BPV INFECTION: PAPILLOMAS AND FIBROPAPILLOMAS}

Infection by Delta-PV leads to the transformation of subepithelial fibroblasts, followed by epithelial acanthosis and papillomatosis, infection by $\mathrm{Xi}-\mathrm{PV}$ induces transformation of the epithelial component only, while Epsilon$P V$ cause both fibropapillomas and epithelial papillomas. The natural history of BPV infection has been extensively studied in experimental conditions [67], although the different stages of the disease are likely to be similar to those occurring in the field. Virus replication can only take place in keratinocytes undergoing terminal differentiation to squamous epithelium. It is therefore only seen in the epithelial component of the tumours and

(page number not for citation purpose) Page 5 of 19 


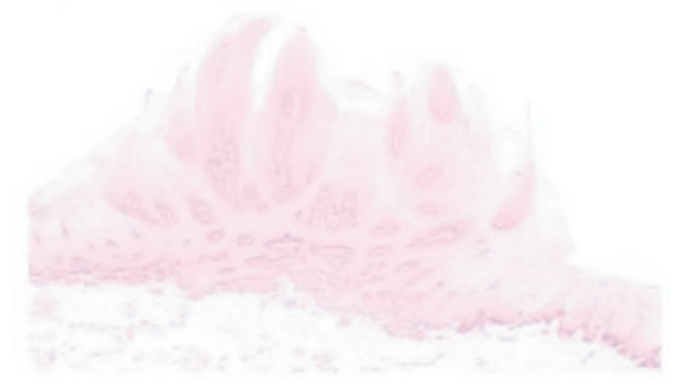

a.

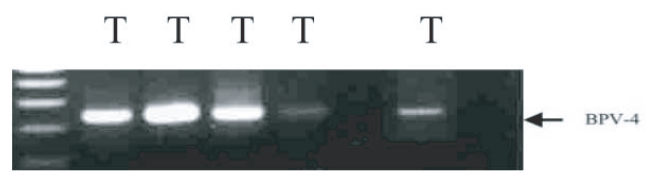

b.

Figure 2. (a) Histological appearance of oesophageal papilloma. Haematoxylin and eosin (H.E.) staining. Magnification $\times 120$. (b) PCR amplification of BPV DNA in bovine oesophageal papilloma. The arrow on the right indicates the position of the $166 \mathrm{bp} \mathrm{BPV-4} \mathrm{L1} \mathrm{PCR} \mathrm{product} \mathrm{in} \mathrm{different} \mathrm{tumour} \mathrm{samples} \mathrm{(T).}$

only at certain stages of its development. Virus replication has never been found in fibroblasts where the BPV genome is present in a nonintegrated episomal form [67].

Papillomas and fibropapillomas may occur in different organs in cattle, in which different BPV genotypes are found. Some still unidentified types infect the vulvo-vaginal epithelium and the eyes [52, 59]. BPV-1 causes teat and penile fibropapillomas; $\mathrm{BPV}-2$ is associated to cutaneous warts, alimentary fibropapillomas and urinary bladder tumours; BPV-3 causes cutaneous papillomas [104]; BPV-4 is associated with pure epithelial papillomas of the upper gastrointestinal (GI) tract; BPV-5 induces rice grain fibropapillomas of the udder; BPV-6, frond papillomas of the teats; BPV-8 causes cutaneous papillomas; BPV-9/10 are associated to epithelial squamous papillomas of the udder. Fibropapillomas and papillomas of teats and udders in cows can become a great economic problem once the papillomas spread along the perineum and the lower part of the body [35]. The spreading may be so extensive that milking becomes difficult or impossible. Distortion of milk ducts and mastitis occur and veals are unable to suckle properly. Macroscopically, a bulging mass of a few centimetres is seen below the skin; this increases its diameter and becomes rough and pendulous until a proper papillomatous feature is reached.

Page 6 of 19 (page number not for citation purpose)
Fibropapillomas occurring both in the prepuce and penis frequently bleed and necrotic areas are present. Fibropapillomas can spread along the perineum and even up toward the back. Since sick animals generally lick the lesions, these spread to the muzzle and mouth. The fibropapillomas can cause loss of reproductive function and may lead animals to slaughter [67].

BPV-2 induced skin warts are usually seen on the forehead, neck, upper thorax and back, and extensive outbreaks of papillomatosis are seen when young animals are housed. They often rub the skin against different objects so that lesions appear and develop ranging from 2 to 10 centimeters. Widespread cutaneous involvement may occur and inanition can lead the animals to death.

Epithelial papillomas of the upper gastrointestinal (GI) tract can appear in every site from the mouth to the rumen. Histologically, they have the classical features of benign papillomas: they are composed of multiple papillary fronds of varying widths, the surfaces of which are covered with the multiple-layered keratinised epithelium (Fig. 2). Acanthosis and parakeratosis of the epithelium is also observed and active viral replication takes place during development, resulting in inclusion bodies visible in the nuclei of infected cells $[18,58]$.

The gastrointestinal tract may be affected even by fibropapillomas which are mostly seen 
in the esophagus and rumen as small peduculated masses or white plaque-like lesions.

The development of the BPV induced fibropapilloma has been largely investigated and different stages have been recognised. After one month of latency, the tumour develops as a fibroma alone or plus acanthosis, a fibropapilloma and regressive tumour [67]. Histologically, an active proliferation of anaplastic fibroblasts with large nuclei gives rise to a subcutaneous mass stretching the overlying epithelium. The histologic appearance is that of a benign fibroma in which viral DNA is episomally with neither viral antigens nor virions produced. Subsequentely, proliferation of basal and keratinocyte layers of the epithelium starts and the proliferating epithelium grows downward towards the mesenchymal mass. The granular cell layer of the epithelium increases in thickness, and clear central areas in the nuclei appear. Viral replication takes place in the nuclei and, since the cells develop into more differentiated layers, the viral particles spread from the cells among the keratinised plates. Finally, the tumour is infiltrated by macrophages and lymphocytes as the regression phenomena hence take place. The lifetime of the process has been established in experimental conditions; it lasts about one year from induction to regression. The development of BPV-2 alimentary fibropapillomas lacks the viral replication stage and seems to be most likely an abortive infection with no viral progeny produced. Further studies on naturally occurring cutaneous fibropapillomas have clarified the role of the virus and its oncoproteins in the neoplastic process. In basal layer keratinocytes, E5 is expressed intracytoplasmically at low levels, whereas abundant amounts of oncoprotein are expressed within highly differentiated keratinocytes in close association with sites of viral capsid protein synthesis [25]. Another subsequent study by Bohl et al. (2001) [14] demonstrated that the BPV-1 E7 oncoprotein is expressed in the cytoplasm and nucleoli of both basal and lower spinous epithelial cells of fibropapillomas and is co-expressed with E5 in basal cells. Additionally, E7 cooperates with E5 and E6 in an anchorage independent transformation assay. The role of the virus is then clear: E5 oncogene plays a role in growth transformation as well as in the differentiation-linked process of viral maturation, thus supporting the hypothesis that these cells are maintained in a transformed state by viral transforming gene expression. Additionally, E7 may modulate the cellular response of basal epithelial cells to E5 expression [14].

Although BPV plays a pivotal role in papillomas and carcinomas, it is noteworthy that BPV DNA is also found in normal bovine skin, indicating that the virus is present in a latent state in apparently healthy animals with no clinical sign of the disease [19]. It is possible that inflammatory cytokines produced as a consequence of the skin lesions may re-activate the latent virus whose gene expression may lead to papilloma development [35]. Moreover, circulating lymphocytes of cattle also harbour BPV DNA in episomal form [31]. This indicates that lymphocytes are another site of viral latency although the exact biological significance needs further investigation.

\section{BRACKEN FERN AS A COFACTOR FOR CARCINOGENESIS}

BPV is in balance with the host. It needs to overcome the host's immune response to replicate and produce infectious progeny. However, the host may be able to mount an effective immune response and thus eliminate the virus and the viral-infected cells. Occasionally, animals may not be able, especially if immunocompromised, to overcome the virus, and so the lesions persist and spread. Persistent PV-lesions are at high risk of progression to cancer.

The major environmental co-factor identified in BPV associated carcinogenesis is bracken fern.

Beyond its toxic effects, bracken fern is also recognised as the only plant known to naturally cause cancer in animals [126]. Cows affected by Bovine Enzootic Haematuria $(\mathrm{BEH})$ frequently develop cancer of the urinary bladder, of both epithelial and mesenchymal origin, and of the alimentary tract. 
Along with immunosuppressants and mutagens - such as quercetin, bracken fern also contains a carcinogenic norsesquiterpene glucoside: ptaquiloside. It possesses the structure of an illudane and is quite unstable in mildly acidic or basic conditions, decomposing into an illudane-dienone. Additionally, the ptaquiloside aglycone ptaquilosin is also very unstable and decomposes into the same dienone $[3,15]$. The dienone has been shown to alkylate DNA via a reactive cyclopropyl ring to form a number of different DNA adducts at $\mathrm{N} 3$ of adenines, which can lead to point mutations. Bracken-fed calves harbour ptaquiloside induced DNA adducts as well as H-ras mutation in the adenine residue of codon 61 in the target organ, the ileum [107]. Moreover, the carcinogenicity of ptaquiloside has been experimentally shown in mice and rats in which tumours developed and DNA adducts and $\mathrm{H}$-ras mutations were found $[53,120,121]$.

The flavonoid quercetin $\left(3,3^{\prime}, 4^{\prime}, 5,7-\right.$ pentahydroxyflavone) is present at high concentrations in the fronds of the fern. Quercetin is mutagenic in both prokaryotic and eukaryotic cells, and is clastogenic, leading to single-strand DNA breaks $[33,106]$ and chromosomal rearrangements [77]. It promotes the full in vitro transformation of primary bovine cells infected with BPV-4 DNA [26, 99] and upregulates viral DNA transcription via a cis-acting element in the viral transcriptional promoter [42]. Moreover, bracken eating cattle with $\mathrm{BEH}$ and/or suffering from bladder cancer develop chromosomal abnormalities [67, 80, 88, 101, 129] due to a clastogenic activity of compounds from fern. Metabolites from ptaquiloside and quercetin along with other chemicals from bracken are also found in the blood, urine and milk of cows naturally exposed to bracken and suffering from bladder cancer $[15,80]$. Exposure to ptaquiloside indirectly through milk from bracken-grazing cows has a big impact on human health, since it has been correlated with human oesophageal and gastric cancer $[3,122,139]$. In different parts of the world the human consumption of bracken has been linked to GI cancer [2, 3, 82]. HPV-16 DNA has been found in high percentage in oesophageal cancer particularly in developing countries where the consumption of bracken or milk from bracken fed cows is high $[79,84]$. A large body of evidence suggests that some human GI cancer may have the same etiology as in cattle opening the possibility that similar etiopathogenetic mechanisms may even occur in humans.

\section{BPV-4 AND GASTROINTESTINAL TUMOURS}

In cattle, BPV-4 infects the mucosa of the upper GI tract leading to the formation of papillomas [27]. BPV-4 infection and associated tumours of the upper GI tract have been found in Brazil, the Nasampolai Valley of Kenya, the Western Highlands of Scotland and in southern Italy $[18,66]$.

Healthy cattle normally recover from papillomatosis in approximately one year's time through a cell-mediated immune response. The characterisation of regression has been studied in biopsies of BPV-4 induced papillomas where, during regression, a great number of activated lymphocytes accumulate in the derma underlying the papilloma [74]. CD4 ${ }^{+}$ lymphocytes are the predominant subtype, with only few $\mathrm{CD}^{+}$and $\gamma \delta\left(\mathrm{WC}^{+}\right)$lymphocytes. $\mathrm{CD}^{+}$lymphocytes are recruited into regressing papillomas and, although all three lymphocyte subsets can penetrate the papilloma, only the $\mathrm{CD}^{+}$and $\gamma \delta\left(\mathrm{WC1}^{+}\right)$lymphocytes are able to penetrate the fronds and the basal layer [74]. The lymphocytes do not proliferate at the site of the regressing papillomas and the contribution of the individual lymphocyte subtypes to regression remains to be established. If the animals are unable to overcome the infection, they may even die of widespread papillomatosis. In this regard, it has been recently shown that in naturally occurring papillomas the E5 viral oncoprotein downregulates MHC-I, thus allowing the virus to evade host immunosurveillance and persist in the infected epithelia [7].

Chronic exposure to immunosuppressants leads to the persistence and spreading of the papillomas. Commonly, immunosuppression in cattle results from exposure to bracken 


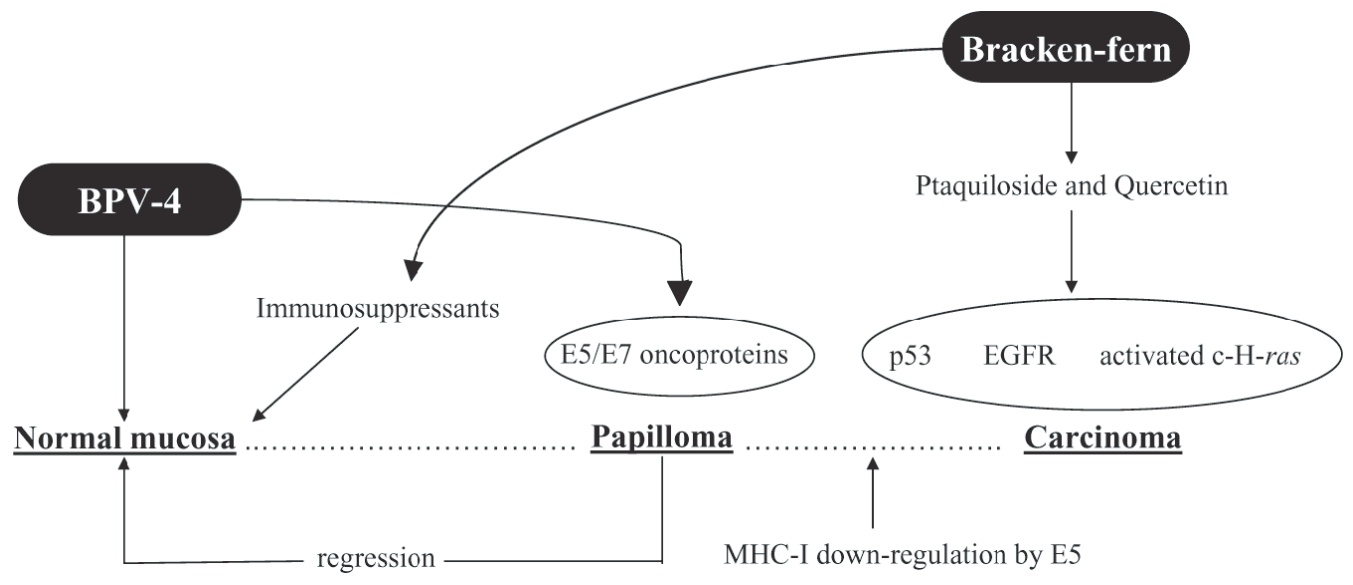

Figure 3. Schematic diagram representing the relationship between BPV-4 and bracken fern in the development of gastrointestinal tumours. BPV-4 is latent in normal epithelium due to the immunosuppressant action of bracken. The papillomas may spread, the viral oncoproteins are expressed and a malignant transformation may occur. p53, Epidermal Growth Factor receptors and c-H-ras are activated in upper gastrointestinal carcinomas.

fern [126] but may even be due to some other factors such as infection with bovine viral diarrhoea virus [137].

Animals with extensive papillomatosis are at high risk to develop cancer, such as squamous cell carcinoma. Latent BPV is activated and full malignant transformation depends on other mutagens such as quercetin and ptaquiloside, which act synergistically with the virus in the carcinogenic process, triggering BPV gene expression and leading to the development of cancer. Two oncogenes may play a role in this event: Ha-ras which has been found activated [28] and a mutated p53. It is possible that both p53 and H-ras may represent targets for carcinogens from bracken (Fig. 3).

Insights into the molecular mechanisms underlying carcinogenesis of the upper GI have been provided by several studies in vitro using bovine palate primary cells (PalF). These cells need an activated H-ras gene for transformation [65] and a mutated p53 to undergo neoplastic transformation [118]. Once PalF cells are transfected with BPV-4 and $\mathrm{H}$-ras, treatment with quercetin alone leads to oncogenic transformation [99]. In this system, quercetin confers anchorage-independence, immortalisation and tumourigenicity, so that the only BPV-4 oncogene required for full transformation is E7 [26]. A cis-acting element responding to quercetin has been mapped in the BPV-4 LCR [42] whose activation leads to E7 oncoprotein expression. This likely induces the transformed cells to bypass the quercetin-induced G1 cell cycle arrest and to proliferate [13].

These transforming events are due to the synergism between bracken fern mutagens (quercetin and ptaquiloside) and BPV-4, but still remain to be established in vivo.

\section{BPV-1/2 AND URINARY BLADDER TUMOURS}

In cattle, tumours of the urinary bladder are commonly associated with BEH, with a prevalence as high as $90 \%$ in adult animals [97]. Field cases of urinary bladder cancer in cattle occur wherever bracken fern is spread. The disease is known to occur in continental Europe, the Azores Islands, in some regions of Kenya, Brasil, New Zealand, India and in China.

It was first suggested in the 1960s that a Papillomavirus could be associated with bladder cancer in cattle [96]. Since then 


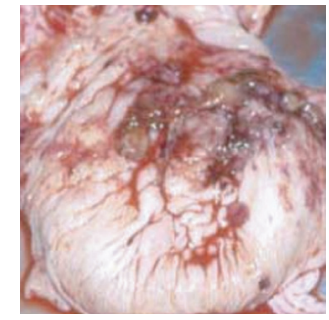

a.

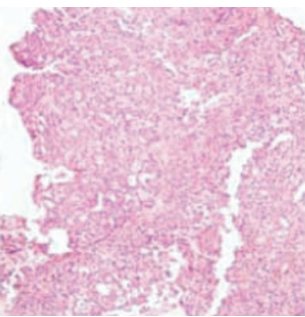

b.

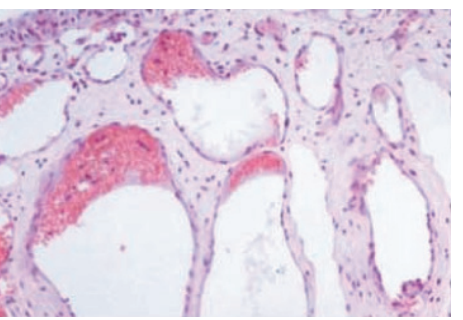

c.

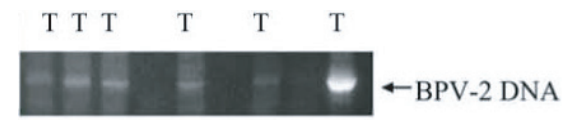

d.

Figure 4. (a) Macroscopic appearance of bovine urinary bladder tumours; (b) Histological appearance of grade II papillary urothelial carcinoma. (H.E. staining). Magnification $\times 120$. (c) Histological apperance of cavernous haemangioma of the urinary bladder. (H.E. staining). Magnification $\times 240$; (d) PCR amplification of BPV DNA in bovine urinary bladder cancer. The arrow on the right indicates the position of the $307 \mathrm{bp}$ BPV-2 E5 PCR product in different tumour samples (T).

Campo et al. (1992) established, in a milestone work, a strong relationship between BPV-2 and bracken fern in bovine bladder carcinogenesis [29]. In this long experimental study, cows fed bracken developed urinary bladder cancers of both epithelial and vascular origin (haemangiomas and haemangiosarcomas) mostly occurring together in the same bladder. BPV-2 DNA was found in $69 \%$ of experimentally induced tumours and in $46 \%$ of naturally occurring ones. This outstanding experiment clearly demonstrates the close relationship between BPV and urinary bladder neoplasia, and that the virus can be activated once the animals are exposed to bracken co-carcinogens and immunosuppressants.

Since then, experiments on naturally occurring bladder neoplasia remained scanty until Borzacchiello et al., [19] showed BPV-2 DNA positivity in about $77 \%$ of bladder cancer and $50 \%$ of normal mucosal samples of healthy cattle in a large population from southern Italy (Fig. 4). Moreover, it was also demonstrated that the virus does play a role in the neoplastic process since its major transforming protein E5 is expressed only in cancer samples but not in normal ones. The analysis of naturally occurring cases of carcinomas from other countries (e.g. Romania) yielded similar findings, showing that BPV-2 DNA presence is not incidental and that the virus is widely spread in continental Europe [10]. BPV-2 E5 interacts with the PDGF $\beta$ receptor in both epithelial and vascular tumours of the urinary bladder, suggesting a possible role of the virus even in mesenchymal carcinogenesis [21,22].

Although the synergism between the virus and bracken is still poorly understood, this large body of evidence suggests that BPV-2 likely infects the bladder mucosa, producing an abortive latent infection, since no structural proteins nor virions have been found in the urinary bladder mucosa $[19,29]$. The exposure to immunosuppressants, mutagenic and carcinogenic principles from bracken triggers viral gene expression, leading to cell transformation and initiating the progression to malignancy [33]. Pathological events taking place in BPV-2 associated urothelial cancers are the upregulation of the telomerase activity which may correlate with the reported ability of Papillomavirus to affect such upregulation [19]. Additionally, the $\mathrm{H}$-ras oncogene is overexpressed (personal 
observations) and a silent mutation (D38D) was detected in a mixed bladder tumour [113]. The mutated site did not correspond to those on codons 12, 59 and 61, described by Prakash et al., (1996) [107] indicating that different mechanisms may act on this oncogene. The $\mathrm{H}$-ras overexpression supports the role of both BPV and bracken in the etiopathogenesis of bladder neoplasia, since this oncogene is found activated in bracken fed cows suffering from alimentary cancers as well as in in vitro artificial systems.

In BPV infected bladder cancers both the cyclooxygenase -1 and -2 isoforms are overexpressed [17]. This maybe related to the ability of $\mathrm{H}$-ras to upregulate the expression of the cyclooxygenase -2 as already shown in transformed cancer cells [55, 123]. However, the overactivation of arachidonic acid metabolism may also be related to BPV-1 E5 whose transforming ability has also been linked to the activation of this metabolic pathway in monkey and human cell lines [138].

Finally, as already observed in HPV associated cervical cancer, the fragile sites are disrupted and the expression of the tumour suppressor fragile histidine tetrads (FHIT) is down-regulated [16] (Fig. 5). Transitional epithelial tumours in cows suffering from $\mathrm{BEH}$ do not metastatise frequently. Recent investigations support the hypothesis that, on the contrary to the high metastatising potential of human transitional tumours, the content of sialic acid and gangliosides of bovine bladder cancer may contribute to this different biological behaviour [111].

BPV-2 DNA has also been found in the bloodstream of cows suffering from $\mathrm{BEH}$ and bladder cancer, suggesting that peripheral blood cells may act as a reservoir for the latent virus and open the possibility of an antemortem diagnosis of the disease [personal observations; 140].

The different histological features of the urinary bladder lesions associated with $\mathrm{BEH}$ have been extensively studied by different research groups [20, 37, 98]. The cancer is of both epithelial and mesenchymal origin (mostly haemangioma and its malignant counterpart) with multiple tumours developing in the same bladder. Non-neoplastic lesions are often associated with neoplasia and should be also taken into account for a histological diagnosis. Due to a lack standardised veterinary classification, non neoplastic lesions are presently grouped in various ways by different veterinary pathologists. The most frequent non neoplastic epithelial abnormalities observed by different research groups are the following: hyperplasia, von Brunn's nests, cystitis cystica, glandular metaplasia (cystitis glandularis and intestinal metaplasia), squamous metaplasia, and nephrogenic adenoma [98; personal observations]. Epithelial neoplasms are more common than mesenchymal ones and mostly malignant. Features of inverted papillomas, i.e. a benign tumour with an inverted growth pattern, and of papillary neoplasms of apparently low malignant potential have also been described. Different histological variants or patterns of transitional cell carcinomas have been identified: pagetoid, micropapillary, nested, mycrocystic and lipid cell variant; trabecular carcinoma with Paneth cell differentiation; mesonephroid adenocarcinoma, 'signet ring' cell carcinoma, plasmocytoid and chromophobe cell carcinoma [16, 20, 37, 98]. Mesenchymal tumours are also very frequent and, in addition to haemangiomas and haemangiosarcomas, fibromas and myxomas are often encountered. A rare case of multiple glomic tumours of the urinary bladder has also been described [112].

Epithelial tumours exhibit altered uroplakins (urothelium-specific and differentiation-dependent proteins) expression due to the lost ability of urothelium to terminally differentiate, uroplakins may therefore be used as a sensitive marker for bovine urothelial tumours [4, 110].

\section{IMMUNITY AND VACCINES}

The immune response of cattle against BPV is very poor. This may be in part due to the fact that the life cycle of the virus is confined to the epithelia, which could also be the underlying cause of the persistent infection [36]. Additionally, viruses have also developed mechanisms whereby they 


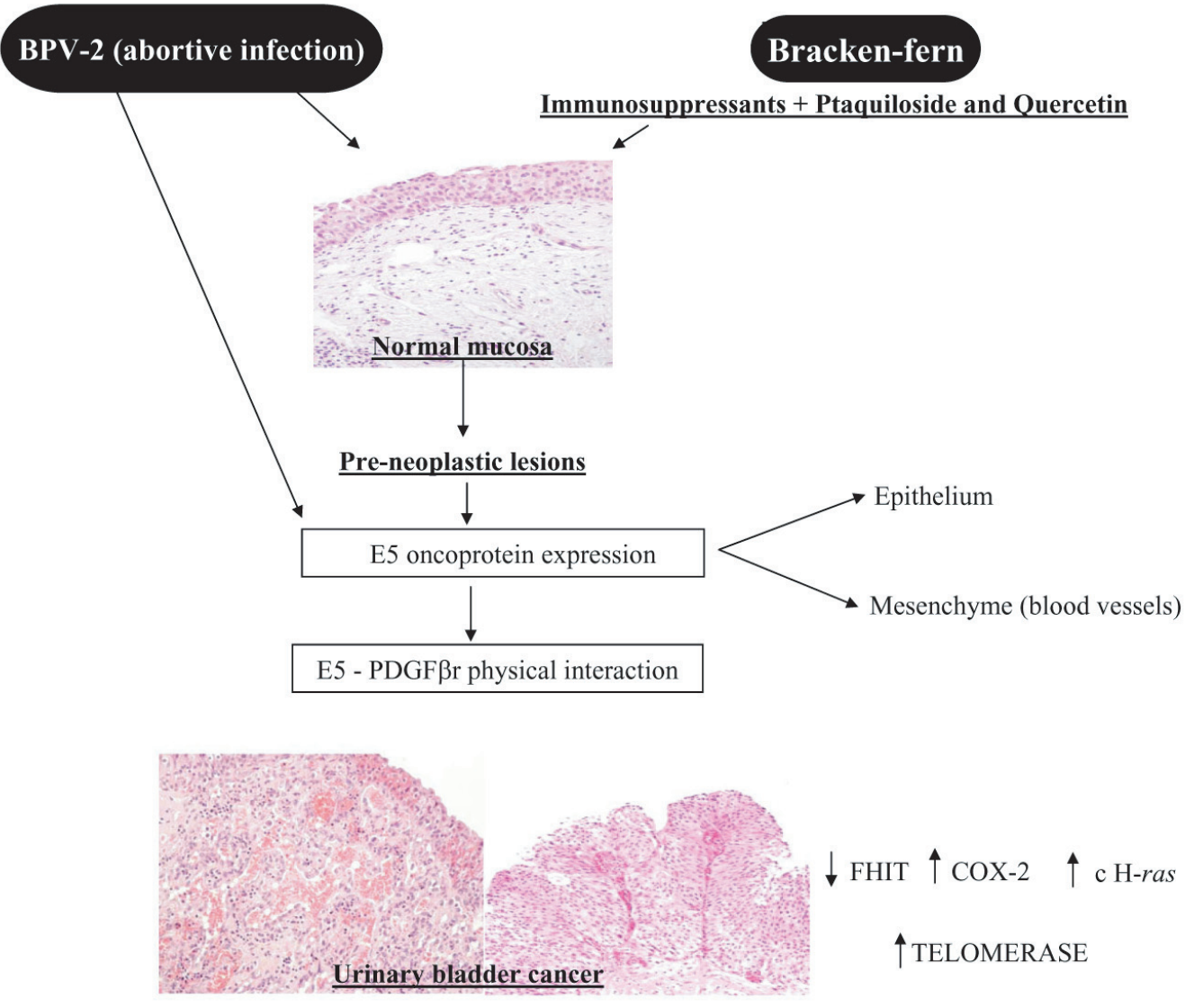

Figure 5. Schematic representation of the events leading to urinary bladder cancer in cattle grazing bracken fern. The BPV-2 infects the bladder mucosa. Chemicals from bracken fern synergise with the virus triggering viral oncogene (E5, E7) expression. The binding of E5 to the activated form of the platelet-derived growth factor $\beta$ receptor (PDGF $\beta r$ ), the overexpression of the cyclooxygenase-2 (COX-2), c-H-ras and the telomerase as well as the down-regulation of the Fragile Histidine Tetrads are cellular events taking place in the BPV-2 associated urinary bladder cancer investigated so far.

escape immunosurveillance. Vaccines have been developed against BPV-2 and BPV-4. In a first attempt to vaccinate calves, viral particles were inoculated. The vaccination prevented infection from challenge virus, and protection was paralleled by the production of virus-neutralising antibodies [68]. Immunity was type-specific with calves protected from infection with the BPV type of the vaccine, not from other types [69].

BPV-2 L1 vaccines induce production of virus neutralising antibodies and prevent infection [70]. A similar effect was obtained with BPV-1 L1 which protected calves against BPV-1 challenge after vaccination [105]. Importantly, only the sera from animals inoculated/immunised with intact virions were capable of neutralising BPV-1 infectivity of murine $\mathrm{C} 127$ cells [71].

BPV-2 L2 vaccines induce regression of warts in which large infiltration of lymphocytes and macrophages are seen. Antibodies against the antigen are produced but are not neutralising [34]. 
Vaccination of cattle with BPV-4 L2 induces long-lasting immunity (more than a year), protecting animals from challenges by BPV-4 [30, 32]. Immunity is conferred by the $\mathrm{N}$-terminus of L2 and the cows develop serum neutralising antibodies against this portion of the protein. The neutralising activity can be abrogated by absorbing the immune sera with L2 or L2a $[39,54]$. Virus neutralisation by anti-L2 antibodies prevents viral DNA replication, but not virus entry into the cell since viral DNA is detected at the virus injection site; the mechanisms underlying viral neutralisation are still unknown [124]. Similar results were achieved with the L1 portion of BPV-1 although in this case the production of neutralising antibodies was doubtful. The neutralising epitopes of the Bovine papillomavirus L2 minor capsid protein were mapped to the $\mathrm{N}$-terminal half of L 2 by blocking the neutralising activity of fulllength L2 antiserum with bacterially expressed peptides of L2 [109].

Expression of L1 and L2, or L1 alone, in eukaryotic cells results in the self-assembly of the proteins into virus-like particles (VLP) which are structurally and antigenically similar to their virion counterparts [72]. L1-VLP and L1-L2 VLP are highly immunogenic, conferring protection from challenge with BPV-4 [34]. Prevention of BPV-4 infection by vaccination with L1-VLP shows that L1 by itself encodes neutralising antibodies. Vaccination with BPV-4 L1 and L2 or only L1-VLP efficiently prevents the development of experimentally induced papillomas, whereas its effect as a therapeutic mean against an established papillomas is equivocal [73].

Vaccination of cattle with E7 reduces the growth of papillomas inducing their regression which is accompanied by a strong cellular immune response [30]. Although vaccinated calves are not protected from infection, they produce anti-E7 antibodies and generate E7specific activated T-cells [38]. T-lymphocytes from vaccinated animals show an increased proliferation activity in the presence of E7, whereas T-lymphocytes from controls show a rather feeble response [86].

\section{CONCLUSIONS}

BPV has always been considered as a model to investigate HPV. It is useful to understand the oncogenic potential of the virus, the relationship between virus and co-factors, and the development of anti-viral vaccines. Recent insights into the mechanisms of BPV proteins such as E5, E7 and E2 and recent discoveries about the association of BPV with mesenchymal tumours demonstrate that BPV can still open new fields of speculation and add new perspectives about PV biology. In addition, the bovine model should also provide an excellent experimental approach to further identify cellular mechanisms involved in the control of PV infection and carcinogenesis.

Finally, the work done in the BPV system paves the way to elucidating the immunological mechanisms controlling viral infection.

Acknowledgements. Giuseppe Borzacchiello wishes to dedicate this work to his wife Valeria.

The authors are very grateful to Prof. MariaSaveria Campo (Institute of comparative medicine - Glasgow - Scotland) and Dr. Aldo Venuti (Istituto per lo studio e la ricerca sul cancro "Regina Elena" - Rome Italy) for all the time they have always generously dedicated to many interesting discussions on this topic. Many thanks are also due to all the colleagues who have been working at the Division of General Pathology and Anatomic pathology (Department of Pathology and Animal health) since 1999, whose contribution made this work possible. We are also deeply grateful to all veterinarians working on the field for having monitored cattles suffering from $\mathrm{BEH}$ and/or urinary bladder cancer in different areas of southern Italy (mainly Campania and Calabria). The support by Progetto di Ricerca di Interesse Nazionale (PRIN) Ministero dell'Università e Ricerca Scientifica $\mathrm{n}^{\circ}$ prot. $2006078044-2006 / 2008$ and Legge Regionale $\mathrm{n}^{\circ} 5$ (2006) from Regione Campania is gratefully acknowledged.

\section{REFERENCES}

[1] Abroi A., Ilves I., Kivi S., Ustav M., Analysis of chromatin attachment and partitioning functions of bovine papillomavirus type $1 \mathrm{E} 2$ protein, J. Virol. (2004) 78:2100-2113.

[2] Alonso-Amelot M.E., Castillo U., Smith B.L., Lauren D.R., Bracken ptaquiloside in milk, Nature (1996) 382:587. 
[3] Alonso-Amelot M.E., Avendaño M., Human carcinogenesis and bracken fern: a review of the evidence, Curr. Med. Chem. (2002) 9:675686.

[4] Ambrosio V., Borzacchiello G., Bruno F., Galati P., Roperto F., Uroplakin expression in the urothelial tumors of cows, Vet. Pathol. (2001) 38:657660.

[5] Anderson R.A., Scobie L., O'Neil B.W., Grindlay G.J., Campo M.S., Viral proteins of bovine papillomavirus type 4 during the development of alimentary canal tumours, Vet. J. (1997) 154:69-78.

[6] Antonsson A., Hansson B.G., Healthy skin of many animal species harbors papillomaviruses which are closely related to their human counterparts, J. Virol. (2002) 76:12537-12542.

[7] Araibi E.H., Marchetti B., Ashrafi G.H., Campo M.S., Downregulation of major histocompatibility complex class I in bovine papillomas, J. Gen. Virol. (2004) 85:2809-2814.

[8] Ashrafi G.H., Pitts J.D., Faccini A., McLean P., O'Brien V., Finbow M.E., Campo M.S., Binding of bovine papillomavirus type 4 E8 to ductin (16K proteolipid), down-regulation of gap junction intercellular communication and full cell transformation are independent events, J. Gen. Virol. (2000) 81:689694.

[9] Ashrafi G.H., Tsirimonaki E., Marchetti B., O'Brien P.M., Sibbet G.J., Andrew L., Campo M.S., Down-regulation of MHC class I by bovine papillomavirus E5 oncoproteins, Oncogene (2002) 21:248-259.

[10] Balcos L.G., Borzacchiello G., Russo V., Popescu O., Roperto S., Roperto F., Association of Bovine papillomavirus type-2 and urinary bladder tumours in cattle from Romania, Res. Vet. Sci. (2008) 85:145-148.

[11] Bastien N., McBride A.A., Interaction of the papillomavirus E2 protein with mitotic chromosomes, Virology (2000) 270:124-134.

[12] Baxter M.K., McPhillips M.G., Ozato K., McBride A.A., The mitotic chromosome binding activity of the papillomavirus E2 protein correlates with interaction with the cellular chromosomal protein Brd4, J. Virol. (2005) 79:4806-4818.

[13] Beniston R.G., Morgan I.M., O’Brien V., Campo M.S., Quercetin, E7 and p53 in papillomavirus oncogenic cell transformation, Carcinogenesis (2001) 22:1069-1076.

[14] Bohl J., Hull B., Vande Pol S.B., Cooperative transformation and coexpression of bovine papillomavirus type 1 E5 and E7 proteins, J. Virol. (2001) 75:513-521.

Page 14 of 19 (page number not for citation purpose)
[15] Bonadies F., Borzacchiello G., Dezzi S., Nicoletti R., Roperto S., Mass spectrometric analysis of ptaquiloside, the toxic sesquiterpene from bracken fern, Rapid Commun. Mass Spectrom. (2004) 18:825828.

[16] Borzacchiello G., Ambrosio V., Galati P., Poggiali F., Venuti A., Roperto F., The pagetoid variant of urothelial carcinoma in situ of urinary bladder in a cow, Vet. Pathol. (2001) 38:113-116.

[17] Borzacchiello G., Ambrosio V., Galati P., Perillo A., Roperto F., Cyclooxygenase-1 and -2 expression in urothelial carcinomas of the urinary bladder in cows, Vet. Pathol. (2003) 40:455-459.

[18] Borzacchiello G., Ambrosio V., Roperto S., Poggiali F., Tsirimonakis E., Venuti A., et al., Bovine papillomavirus type 4 in oesophageal papillomas of cattle from the south of Italy, J. Comp. Pathol. (2003) 128:203-206.

[19] Borzacchiello G., Iovane G., Marcante M.L., Poggiali F., Roperto F., Roperto S., Venuti A., Presence of bovine papillomavirus type 2 DNA and expression of the viral oncoprotein E5 in naturally occurring urinary bladder tumours in cows, J. Gen. Virol. (2003) 84:2921-2926.

[20] Borzacchiello G., Ambrosio V., Leonardi L., Fruci R., Galati P., Roperto F., Rare tumours in domestic animals: a lipid cell variant of urothelial carcinoma of the urinary bladder in a cow and a case of vesical carcinosarcoma in a dog, Vet. Res. Commun. (2004) 28:273-274.

[21] Borzacchiello G., Russo V., Gentile F., Roperto F., Venuti A., Nitsch L., et al., Bovine papillomavirus E5 oncoprotein binds to the activated form of the plateletderived growth factor beta receptor in naturally occurring bovine urinary bladder tumours, Oncogene (2006) 25:1251-1260.

[22] Borzacchiello G., Russo V., Spoleto C., Roperto S., Balcos L., Rizzo C., et al., Bovine papillomavirus type-2 DNA and expression of E5 and E7 oncoproteins in vascular tumours of the urinary bladder in cattle, Cancer Lett. (2007) 250:82-91.

[23] Borzacchiello G., Bovine papillomavirus, in: Schwab M. (Ed.), Encyclopedia of Cancer, 2nd ed., Springer-Verlag, Germany, 2008.

[24] Burkhardt A., Willingham M., Gay C., Jeang K.T., Schlegel R., The E5 oncoprotein of bovine papillomavirus is oriented asymmetrically in Golgi and plasma membranes, Virology (1989) 170:334339.

[25] Burnett S., Jareborg N., DiMaio D., Localization of bovine papillomavirus type 1 E5 protein to transformed basal keratinocytes and permissive differentiated cells in fibropapilloma tissue, Proc. Natl. Acad. Sci. USA (1992) 89:5665-5669. 
[26] Cairney M., Campo M.S., The synergism between bovine papillomavirus type 4 and quercetin is dependent on the timing of exposure, Carcinogenesis (1995) 16:1997-2001.

[27] Campo M.S., Moar M.H., Jarrett W.F.H., Laird H.M., A new papillomavirus associated with alimentary cancer in cattle, Nature (1980) 286:180-182.

[28] Campo M.S., McCaffery R.E., Doherty I., Kennedy I.M., Jarrett W.F.H., The Harvey ras 1 gene is activated in papillomavirus associated carcinomas of the upper alimentary canal in cattle, Oncogene (1990) 5:303-308.

[29] Campo M.S., Jarrett W.F., Barron R., O’Neil B.W., Smith K.T., Association of bovine papillomavirus type 2 and bracken fern with bladder cancer in cattle, Cancer Res. (1992) 52:6898-6904.

[30] Campo M.S., Grindlay G.J., O’Neil B.W., Chandrachud L.M., McGarvie G.M., Jarrett W.F.H., Prophylactic and therapeutic vaccination against a mucosal papillomavirus, J. Gen. Virol. (1993) 74:945953.

[31] Campo M.S., Jarrett W.F., O’Neil W., Barron R.J., Latent papillomavirus infection in cattle, Res.Vet. Sci (1994) 56:151-157.

[32] Campo M.S., Jarrett W.F., Vaccination against cutaneous and mucosal papillomavirus in cattle. In vaccines against virally induced cancers, Ciba Found. Symp. (1994) 187:61-77.

[33] Campo M.S., Bovine papillomavirus and cancer, Vet. J. (1997) 154:175-188.

[34] Campo M.S., Vaccination against papillomavirus in cattle, Clin. Dermatol. (1997) 15:275-283.

[35] Campo M.S., Animal model of papillomavirus pathogenesis, Virus Res. (2002) 89:249-261.

[36] Campo M.S., Bovine papillomavirus: old system, new lessons?, in: Campo M.S. (Ed.), Papillomavirus research from natural history to vaccines and beyond, Caister Academic Press, Norfolk, 2006, pp. 373-383.

[37] Carvalho T., Pinto C., Peleteiro M.C., Urinary bladder lesions in bovine enzootic haematuria, J. Comp. Pathol. (2006) 134:336-346.

[38] Chandrachud L.M., O’Neil B.W., Jarrett W.F.H., Grindlay G.J., McGarvie G.M., Campo M.S., Humoral immune response to the E7 protein of bovine papillomavirus type 4 and identification of B-cell epitopes, Virology (1994) 200:98-104.

[39] Chandrachud L.M., Grindlay G.J., McGarvie G.M., O'Neil B.W., Wagner E.R., Jarrett W.H.F., Campo M.S., Vaccination of cattle with the N-terminus of L2 is necessary and sufficient for preventing infection by bovine papillomavirus-4, Virology (1995) 211:204-208.
[40] Choy E., Chiu V.K., Silletti J., Feoktistov M., Morimoto T., Michaelson D., et al., Endomembrane trafficking of Ras: the CAAX motif targets proteins to the ER and Golgi, Cell (1999) 98:69-80.

[41] Cohen B.D., Goldstein D.J., Rutledge L., Vass W.C., Lowy D.R., Schlegel R., Schiller J., Transformation-specific interaction of the bovine papillomavirus E5 oncoprotein with the plateletderived growth factor receptor transmembrane domain and the epidermal growth factor receptor cytoplasmic domain, J. Virol. (1993) 67:5303-5311.

[42] Connolly J.A., Morgan I.M., Jackson M.E., Campo M.S., The BPV-4 co-carcinogen quercetin induces cell cycle arrest and up-regulates transcription from the LCR of BPV-4, Oncogene (1998) 21:27392746.

[43] Conrad M., Bubb V.J., Schlegel R., The human papillomavirus type 6 and 16 E5 proteins are membrane-associated proteins which associate with the 16-kilodalton pore-forming protein, J. Virol. (1993) 67:6170-6178.

[44] Day P.M., Schiller J.T., Early events in the papillomaviral life cycle, in: Campo M.S. (Ed.), Papillomavirus research from natural history to vaccines and beyond, Caister Academic Press, Norfolk, 2006, pp. 174-192.

[45] DeMasi J., Huh K.W., Nakatani Y., Münger K., Howley P.M., Bovine papillomavirus E7 transformation function correlates with cellular p600 protein binding, Proc. Natl. Acad. Sci. USA (2005) 102:11486-11491.

[46] DeMasi J., Chao M.C., Kumar A.S., Howley P.M., Bovine papillomavirus E7 oncoprotein inhibits anoikis, J. Virol. (2007) 81:9419-9425.

[47] De Villiers E.M., Fauquet C., Broker T.R., Bernard H.U., zur Hausen H., Classification of papillomaviruses, Virology (2004) 324:17-27.

[48] DiMaio D., Mattoon D., Mechanisms of cell transformation by papillomavirus E5 proteins, Oncogene (2001) 20:7866-7873.

[49] Doorbar J., An emerging function for E4, Papillomavirus Report (1991) 2:145-148.

[50] Drummond-Barbosa D.A., Vaillancourt R.R., Kazlauskas A., DiMaio D., Ligand-independent activation of the platelet-derived growth factor beta receptor: requirements for bovine papillomavirus E5-induced mitogenic signalling, Mol. Cell. Biol. (1995) 15:2570-2581.

[51] Faccini A.M., Cairney M., Ashrafi G.H., Finbow M.E., Campo M.S., Pitts J.D., The bovine papillomavirus type 4 E8 protein binds to ductin and causes loss of gap junctional intercellular communication in primary fibroblasts, J. Virol. (1996) 70:9041-9045. 
[52] Ford J.N., Jennings P.A., Spradbrow P.B., Francis J., Evidence for papillomaviruses in ocular lesions in cattle, Res. Vet. Sci. (1982) 32:257-259.

[53] Freitas R.N., O'Connor P.J., Prakash A.S., Shahin M., Povey A.C., Bracken (Pteridium aquilinum)induced DNA adducts in mouse tissues are different from the adduct induced by the activated form of the bracken carcinogen ptaquiloside, Biochem. Biophys. Res. Commun. (2001) 281:589-594.

[54] Gaukroger J.M., Chandrachud L.M., O’Neil B.W., Grindlay G.J., Knowles G., Campo M.S., Vaccination of cattle with bovine papillomavirus type 4 L2 elicits the production of virus-neutralizing antibodies, J. Gen. Virol. (1996) 77:1577-1583.

[55] Gilhooly E.M, Rose D.P., The association between a mutated ras gene and cyclooxygenase-2 expression in human breast cancer cell lines, Int. J. Oncol. (1999) 15:267-270.

[56] Goldstein D.J., Finbow M.E., Andresson T., McLean P., Smith K., Bubb V., Schlegel R., Bovine papillomavirus E5 oncoprotein binds to the $16 \mathrm{~K}$ component of vacuolar H(+)-ATPases, Nature (1991) 352:347-349.

[57] Goldstein D.J., Li W., Wang L.M., Heidaran M.A., Aaronson S., Shinn R., et al., The bovine papillomavirus type 1 E5 transforming protein specifically binds and activates the beta-type receptor for the platelet-derived growth factor but not other related tyrosine kinase-containing receptors to induce cellular transformation, J. Virol. (1994) 68:4432-4441.

[58] Hamada M., Oyamada T., Yoshikawa H., Yoshikawa T., Morphological studies of esophageal papilloma naturally occurring in cattle, Nippon Juigaku Zasshi (1989) 51:345-351.

[59] Hamata S., Nobumoto K., Kanno T., Genomic and phylogenetic analysis of two novel bovine papillomaviruses, BPV-9 and BPV-10, J. Gen. Virol. (2008) 89:158-163.

[60] Hill F.W., Klein W.R., Hoyer M.J., Rutten V.P., Kock N., Koten J.W., et al., Antitumour effect of locally injected low doses of recombinant human interleukin-2 in bovine vulval papilloma and carcinoma, Vet. Immunol. Immunopathol. (1994) 41:19-29.

[61] Holden P.R., McGuire B., Stoler A., Balmain A., Pitts J.D., Changes in gap junctional intercellular communication in mouse skin carcinogenesis, Carcinogenesis (1997) 18:15-21.

[62] IARC Monographs on the Evaluation of Carcinogenic Risks to Humans, vol. 64, Human Papillomavirus, IARC, Lyon, France, 1995.

[63] Ilves I., Kivi S., Ustav M., Long term episomal mantenance of bovine papillomavirus type 1 plasmids is determined by attachment to host chromosomes, which is mediated by the viral E2 protein and its binding sites, J. Virol. (1999) 73:4404-4412.

[64] Jackson M.E., Campo M.S., Both viral E2 protein and the cellular factor PEBP2 regulate transcription via E2 consensus sites within the bovine papillomavirus type 4 long control region, J. Virol. (1995) 10:60386046.

[65] Jaggar R.T., Pennie W.D., Smith K.T., Jackson M.E., Campo M.S., Cooperation between bovine papillomavirus type 4 and ras in the morphological transformation of primary bovine fibroblasts, J. Gen. Virol. (1990) 71:3041-3046.

[66] Jarrett W.F.H., McNeil P.E., Grimshaw W.T., Selman I.E., McIntyre W.I.M., High incidence area of cattle cancer with a possible interaction between an environmental carcinogen and a papilloma virus, Nature (1978) 274:215-217.

[67] Jarrett W.F.H., The natural history of bovine papillomavirus infections, in: G. Klein (Ed.), Advances in Viral Oncology, vol. 5, Raven Press, New York, 1985, pp. 83-101.

[68] Jarrett W.F.H., O’Neil B.W., Gaukroger J.M., Laird H.M., Smith K.T., Campo M.S., Studies on vaccination against papillomaviruses: a comparison of purified virus, tumour extracts and transformed cells in prophylactic vaccination, Vet. Rec. (1990) 126:449_ 452.

[69] Jarrett W.F.H., O'Neil B.W., Gaukroger J.M., Smith K.T., Laird H.M., Campo M.S., Studies on vaccination against papillomaviruses: the immunity after infection and vaccination with bovine papillomaviruses of different types, Vet. Rec. (1990) 126:473-475.

[70] Jarrett W.F.H., Smith K.T., O'Neil B.W., Gaukroger J.M., Chandrachud L.M., Grindlay G.J., et al., Studies on vaccination against papillomaviruses: prophylactic and therapeutic vaccination with recombinant structural proteins, Virology (1991) 184:33-42.

[71] Jenson A.B., Lim P., Ghim S., Cowsert L., Olson C., Lim L.Y., et al., Identification of linear epitopes of the BPV-1 L1 protein recognized by sera of infected or immunized animals, Pathobiology (1991) 59:396-403.

[72] Kirnbauer R., Booy F., Cheng N., Lowy D.R., Schiller J.T., Papillomavirus L1 major capsid protein self-assembles into virus-like particles that are highly immunogenic, Proc. Natl. Acad. Sci. USA (1992) 89:12180-12184.

[73] Kirnbauer R., Chandrachud L.M., O’Neil B.W., Wagner E.R., Grindlay G.J., Armstrong A., et al., Virus-like particles of Bovine papillomavirus type-4 in prophylactic and therapeutic immunization, Virology (1996) 219:37-44. 
[74] Knowles G., O’Neil B.W., Campo M.S., Phenotypical characterization of lymphocytes infiltrating regressing papillomas, J. Virol. (1996) 70:8451-8458.

[75] Lai C.C., Henningson C., DiMaio D., Bovine papillomavirus E5 protein induces oligomerization and trans-phosphorylation of the platelet-derived growth factor beta receptor, Proc. Natl. Acad. Sci. USA (1998) 95:15241-15246

[76] Lambert P.F., Papillomavirus DNA replication, J. Virol. (1991) 65:3417-3420.

[77] Leal A.M., Ferraz O.P., Carvalho C., Freitas A.C., Beniston R.G., Campo M.S., et al., Quercetin induces structural chromosome aberrations and uncommon rearrangements in cells transformed by the $\mathrm{E} 7$ protein of BPV-4, Veterinary and Comparative Oncology (2003) 1:15-21.

[78] Lehman C.W., Botchan M.R., Segregation of viral plasmids depends on tethering to chromosomes and is regulated by phosphorylation, Proc. Natl. Acad. Sci. USA (1998) 95:4338-4343.

[79] Li T., Lu Z.M., Chen K.N., Guo M., Xing H.P., Mei Q., et al., Human papillomavirus type 16 is an important infectious factor in the high incidence of esophageal cancer in Anyang area of China, Carcinogenesis (2001) 22:929-934.

[80] Lioi M.B., Barbieri R., Borzacchiello G., Dezzi S., Roperto S., Santoro A., et al., Chromosome aberrations in cattle with chronic enzootic haematuria, J. Comp. Pathol. (2004) 131:233-236.

[81] Marchetti B., Ashrafi T.H., Tsirimonaki E., O'Brien P.M., Campo M.S., The bovine papillomavirus oncoprotein E5 retains MHC class I molecules in the Golgi apparatus and prevents their transport to the cell surface, Oncogene (2002) 51:7808-7816.

[82] Marliere C., Galvao M.A.M., Wather P., Freitas R.N., Bracken fern consumption and oesophageal and gastric cancer in the Ouro Preto region, MG, Brazil, in: Taylor J.A. and Smith R.T. (Eds.), Bracken fern: Toxicity, Biology and Control, 1999, pp. 144-149.

[83] Martin P., Vass W.C., Schiller J.T., Lowy D.R., Velu T.J., The bovine papillomavirus E5 transforming protein can stimulate the transforming activity of EGF and CSF-1 receptors, Cell (1989) 59:21-32.

[84] Matsha T., Erasmus R., Kafuko A.B., Mugwanya D., Stepien A., Parker M.I., Human papillomavirus associated with esophageal cancer, J. Clin. Pathol. (2002) 55:587-590.

[85] Mattoon D., Gupta K., Doyon J., Loll P.J., DiMaio D., Identification of the transmembrane dimer interface of the bovine papillomavirus E5 protein, Oncogene (2001) 20:3824-3834.

[86] McGarvie G.M., Grindlay G.J., Chandrachud L.M., O'Neil B.W., Jarrett W.F., Campo M.S., T cell responses to BPV-4 E7 during infection and mapping of T cell epitopes, Virology (1995) 206:504-510.

[87] Modis Y., Trus B.L., Harrison S.C., Atomic model of the papillomavirus capsid, EMBO J. (2002) 21:4754-4762.

[88] Moura J.W., Stocco dos Santos R.C., Dagli M.L.Z., D’Angelino J.L., Birgel E.H., Beçak W., Chromosome aberrations in cattle raised on bracken fern pasture, Experientia (1988) 44:785-788.

[89] Nilson L.A., DiMaio D., Platelet-derived growth factor receptor can mediate tumourigenic transformation by the bovine papillomavirus E5 protein, Mol. Cell. Biol. (1993) 13:4137-4145.

[90] Nilson L.A., Gottlieb R.L., Polack G.W., DiMaio D., Mutational analysis of the interaction between the bovine papillomavirus E5 transforming protein and the endogenous beta receptor for platelet-derived growth factor in mouse C127 cells, J. Virol. (1995) 69:58695874.

[91] O’Brien V., Campo M.S., BPV-4 E8 transforms NIH3T3 cells, up-regulates cyclin A and cyclin Aassociated kinase activity and de-regulates expression of the cdk inhibitor p27Kip1, Oncogene (1998) 17:293-301.

[92] O’Brien V., Ashrafi G.H., Grindlay G.J., Anderson R., Campo M.S., A mutational analysis of the transforming functions of the E8 protein of bovine papillomavirus type 4, Virology (1999) 255:385-394.

[93] O’Brien V., Grindlay G.J., Campo M.S., Cell transformation by the E5/E8 protein of bovine papillomavirus type 4: p27 $7^{\mathrm{Kip} 1}$, Elevated through increased protein synthesis is sequestered by cyclin D1-CDK4 complexes, J. Biol. Chem. (2001) 276:33861-33868.

[94] Oelze I., Kartenbeck J., Crusius K., Alonso A., Human papillomavirus type 16 E5 protein affects cellcell communication in an epithelial cell line, J. Virol. (1995) 69:4489-4494.

[95] Ogawa T., Tomita Y., Okada M., Shirasawa H., Complete genome and phylogenetic position of bovine papillomavirus type 7, J. Gen.Virol. (2007) 88:1934-1938.

[96] Olson C., Pamukcu A.M., Brobst D.F., Papillomalike virus from bovine urinary bladder tumours, Cancer Res. (1965) 25:840-849.

[97] Pamukcu A.M., Price J.M., Bryan G.T., Naturally occurring and bracken-fern-induced bovine urinary bladder tumours. Clinical and morphological characteristics, Vet. Pathol. (1976) 13:110-122.

[98] Peixoto P.V., França T.N., Barros C.S.L., Tokarnia C.H., Histopathological aspects of Bovine Enzootic Hematuria in Brazil, Pesqui. Vet. Bras. (2003) 23:65-81.

(page number not for citation purpose) Page 17 of 19 
[99] Pennie W.D., Campo M.S., Synergism between bovine papillomavirus type 4 and the flavonoid quercetin in cell transformation in vitro, Virology (1992) 190:861-865.

[100] Pennie W.D., Grindlay G.J., Cairney M., Campo M.S., Analysis of the transforming functions of bovine papillomavirus type 4, Virology (1993) 193:614-620.

[101] Peretti V., Ciotola F., Albarella S., Russo V., Di Meo G.P., Iannuzzi L., et al., Chromosome fragility in cattle with chronic enzootic haematuria, Mutagenesis (2007) 22:317-320.

[102] Petti L., Nilson L.A., DiMaio D., Activation of the platelet-derived growth factor receptor by the bovine papillomavirus E5 transforming protein, EMBO J. (1991) 10:845-855.

[103] Petti L., DiMaio D., Stable association between the bovine papillomavirus E5 transforming protein and activated platelet-derived growth factor receptor in transformed mouse cells, Proc. Natl. Acad. Sci. USA (1992) 89:6736-6740.

[104] Pfister H., Linz U., Gissmann L., Huchthausen B., Hoffmann D., Zur Hausen H., Partial characterization of a new type of bovine papilloma viruses, Virology (1979) 96:1-8.

[105] Pilacinski W.P., Glassman D.L., Glassman K.F., Reed D.E., Lum M.A., Marshall R.F., et al., Immunization against bovine papillomavirus infection, Ciba Found. Symp. (1986) 120:136-156.

[106] Plaumann B., Fritsche M., Rimpler H., Brandner G., Hess R.D., Flavonoids activate wild-type p53, Oncogene (1996) 13:1605-1614.

[107] Prakash A.S., Pereira T.N., Smith B.L., Shaw G., Seawright A.A., Mechanism of bracken fern carcinogenesis: evidence for $\mathrm{H}$-ras activation via initial adenine alkylation by ptaquiloside, Nat. Toxins (1996) 4:221-227.

[108] Roberts S., Ashmole I., Johnson G.D., Kreider J.W., Gallimore P.H., Cutaneous and mucosal human papillomavirus E4 proteins form intermediate filament-like structures in epithelial cells, Virology (1993) 197:176-187.

[109] Roden R.B., Weissinger E.M., Henderson D.W., Booy F., Kirnbauer R., Mushinski J.F., et al., Neutralization of bovine papillomavirus by antibodies to L1 and L2 capsid proteins, J. Virol. (1994) 68:7570-7574

[110] Roperto S., Ambrosio V., Borzacchiello G., Galati P., Paciello O., Russo V., Roperto F., Bovine papillomavirus type-2 (BPV-2) infection and expression of uroplakin IIIb, a novel urothelial cell marker, in urinary bladder tumours of cows, Vet. Pathol. (2005) 42:812-818.

[111] Roperto S., Borzacchiello G., Casellato R., Galati P., Russo V., Sonnino S., Roperto F., Sialic acid

Page 18 of 19 (page number not for citation purpose) and GM3 ganglioside expression in papillomavirusassociated urinary bladder tumours of cattle with chronic enzootic haematuria, J. Comp. Pathol. (2007) 137:87-93.

[112] Roperto S., Borzacchiello G., Brun R., Perillo A., Russo V., Urraro C., Roperto F., Multiple glomus tumors of the urinary bladder in a cow associated with bovine papillomavirus type 2 (BPV-2) infection, Vet. Pathol. (2008) 45:39-42.

[113] Sardon D., de la Fuente I., Calonge E., PerezAlenza M.D., Castaño M., Dunner S., Peña L., H-ras immunohistochemical expression and molecular analysis of urinary bladder lesions in grazing adult cattle exposed to bracken fern, J. Comp. Pathol. (2005) 132:195-201.

[114] Sarver N., Rabson M.S., Yang Y.C., Byrne J.C., Howley P.M., Localization and analysis of bovine papillomavirus type 1 transforming functions, J. Virol. (1984) 52:377-388

[115] Schapiro F., Sparkowski J., Adduci A., Suprynowicz F., Schlegel R., Grinstein S., Golgi alkalinization by the papillomavirus E5 oncoprotein, J. Cell. Biol. (2000) 148:305-315.

[116] Schiller J.T., Vass W.C., Vousden K.H., Lowy D.R., E5 open reading frame of bovine papillomavirus type 1 encodes a transforming gene, J. Virol. (1986) $57: 1-6$.

[117] Schlegel R., Wade-Glass M., Rabson M.S., Yang Y.C., The E5 transforming gene of bovine papillomavirus encodes a small, hydrophobic polipeptide, Science (1986) 233:464-467.

[118] Scobie L., Jackson M.E., Campo M.S., The role of exogenous p53 and E6 oncoproteins in in vitro transformation by bovine papillomavirus type 4 (BPV4): significance of the absence of an E6 ORF in the BPV-4 genome, J. Gen. Virol. (1997) 78:3001-3008.

[119] Settleman J., Fazeli A., Malicki J., Horwitz B.H., DiMaio D., Genetic evidence that acute morphologic transformation, induction of cellular DNA synthesis, and focus formation are mediated by a single activity of the bovine papillomavirus E5 protein, Mol. Cell. Biol. (1989) 9:5563-5572.

[120] Shahin M., Moore M.R., Worrall S., Smith B.L., Seawright A.A., Prakash A.S., H-ras activation is an early event in the ptaquiloside-induced carcinogenesis: comparison of acute and chronic toxicity in rats, Biochem. Biophys. Res. Commun. (1998) 250:491-497.

[121] Shahin M., Smith B.L., Worral S., Moore M.R., Seawright A.A., Prakash A.S., Bracken fern carcinogenesis: multiple intravenous doses of activated ptaquiloside induce DNA adducts, monocytosis, increased TNF alpha levels, and mammary gland carcinomas in rats, Biochem. Biophys. Res. Commun. (1998) 244:192-197. 
[122] Shahin M., Smith B.L., Prakash A.S., Bracken carcinogens in the human diet, Mutat. Res. (1999) 443:69-79.

[123] Sheng G.G., Shao J., Sheng H., Hooton E.B., Isakson P.C., Morrow J.D., et al., A selective cyclooxygenase 2 inhibitor suppresses the growth of H-ras-transformed rat intestinal epithelial cells, Gastroenterology (1997) 113:1883-1891.

[124] Sibbet G., Romero-Graillet C., Meneguzzi G., Campo M.S., alpha6 integrin is not the obligatory cel receptor for bovine papillomavirus type 4, J. Gen. Virol. (2000) 81:327-334.

[125] Skiadopoulos M.H., McBride A.A., Bovine papillomavirus type 1 genomes and the E2 transactivator protein are closely associated with mitotic chromatin, J. Virol. (1998) 72:2079-2088.

[126] Smith B.L., The toxicity of bracken fern (genus Pteridium) to animals and its relevance to man, in D'Mello J.P.F. (Ed.), Handbook of plant and fungal toxicants, CRC Press, Boca Raton, Florida, USA, 1997, pp. 63-76.

[127] Sparkowski J., Mense M., Anders J., Schlegel R., E5 oncoprotein transmembrane mutants dissociate fibroblast transforming activity from 16-kilodalton protein binding and platelet-derived growth factor receptor binding and phosphorylation, J. Virol. (1996) $70: 2420-2430$

[128] Staebler A., Pierce J.H., Brazinski S., Heidaran M.A., Li W., Schlegel R., Goldstein D.J., Mutational analysis of the beta-type platelet-derived growth factor receptor defines the site of interaction with the bovine papillomavirus type $1 \mathrm{E} 5$ transforming protein J. Virol. (1995) 69:6507-6517.

[129] Stocco dos Santos R.C., Lindsley C.J., Ferraz O.P., Pinto J.R., Mirandola R.S., Benesi F.J., et al., Bovine papillomavirus transmission and chromosomal aberrations: an experimental model, J. Gen. Virol. (1998) 79:2127-2135.

[130] Sundberg J.P., Papillomavirus infections in animals, in: Syrjanen K. Gissmann L. Koss L. (Eds.), Papillomaviruses and Human Disease, SpringerVerlag, Heidelberg, Germany, 1987, pp. 40-103.

[131] Sundberg J.P., VanRanst M., Burk R.D., Jenson A.B., The nonhuman (animal) papillomaviruses: host range, epitope conservation, and molecular diversity, in: Gross G., von Krogh G. (Eds.) Human Papillomavirus Infections in Dermatology and Venereology, CRC Press, Boca Raton, Florida, USA, 1996, pp. 47-68.

[132] Suprynowicz F.A., Sparkowski J., Baege A., Schlegel R., E5 oncoprotein mutants activate phosphoinositide 3-kinase independently of platelet-derived growth factor receptor activation, J. Biol. Chem. (2000) 275:5111-5119.
[133] Surti T., Klein O., Aschheim K., DiMaio D., Smith S.O., Structural models of the bovine papillomavirus E5 protein, Proteins (1998) 33:601-612.

[134] Tomita Y., Literak I., Ogawa T., Jin Z., Shirasawa H., Complete genomes and phylogenetic positions of bovine papillomavirus type 8 and a variant type from European bison, Virus Genes (2007) 35:243-249.

[135] Tong X., Salgia R., Li J.L., Griffin J.D., Howley P.M., The bovine papillomavirus E6 protein binds to the LD motif repeats of paxillin and blocks its interaction with vinculin and the focal adhesion kinase, J. Biol. Chem. (1997) 272:33373-33376.

[136] Tong X., Boll W., Kirchhausen T., Howley P.M., Interaction of the bovine papillomavirus E6 protein with the clathrin adaptor complex AP-1, J. Virol. (1998) 72:476-482.

[137] Tsirimonaki E., O’Neil B.W., Williams R., Campo M.S., Extensive papillomatosis of the bovine upper gastrointestinal tract, J. Comp. Pathol. (2003) 129:93-99.

[138] Väli U., Kilk A., Ustav M., Bovine papillomavirus oncoprotein E5 affects the arachidonic acid metabolism in cells, Int. J. Biochem. Cell Biol. (2001) 33:227-235.

[139] Venuti A., Campo M.S., The E5 protein of papillomavirus, in: McCance D. (Ed.), Human Papillomavirus - Perspectives in Medical Virology, vol. 8, Elsevier Science, Amsterdam, 2002, pp. 143-164.

[140] Wosiacki S.R., Barreiro M.A.B., Alfieri A.F., Alfieri A.A., Semi-nested PCR for detection and typing of bovine Papillomavirus type 2 in urinary bladder and whole blood from cattle with enzootic haematuria, J. Virol. Methods (2005) 126:215-219.

[141] You J., Croyle J.L., Nishimura A., Ozato K., Howley P.M., Interaction of the bovine papillomavirus E2 protein with Brd4 tethers the viral DNA to host mitotic chromosomes, Cell (2004) 117:349-360.

[142] Zago M., Campo M.S, O'Brien V., Cyclin $\mathrm{A}$ expression and growth in suspension can be uncoupled from p27 deregulation and extracellular signal-regulated kinase activity in cells transformed by bovine papillomavirus type 4 E5, J. Gen. Virol. (2004) 85:3585-3595.

[143] Zeng L., Zhou M.M., Bromodomain: an acetyl-lysine binding domain, FEBS Lett. (2002) 513:124-128.

[144] Zimmermann H., Koh C.H., Degenkolbe R., O'Connor M.J., Müller A., Steger G., et al., Interaction with $\mathrm{CBP} / \mathrm{p} 300$ enables the bovine papillomavirus type 1 E6 oncoprotein to downregulate $\mathrm{CBP} / \mathrm{p} 300$ mediated transactivation by p53, J. Gen. Virol. (2000) 81:2617-2623. 